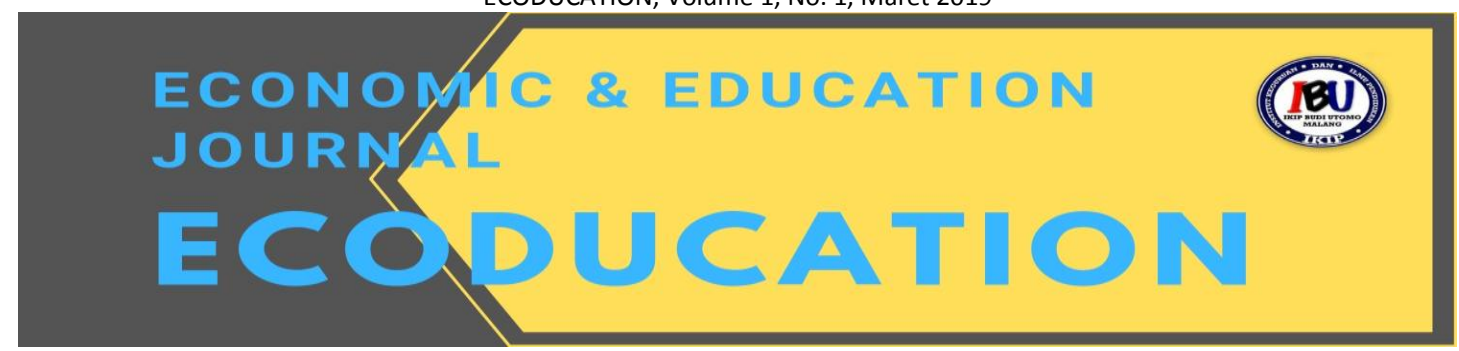

\title{
PENGARUH STATUS SOSIAL EKONOMI TERHADAP KINERJA GURU EKONOMI DI SMA KOTA MALANG
}

\author{
Putri Vina Sefaverdianan, M.Pd, \\ IKIP Budi Utomo Malang \\ email: viseverputri@gmail.com
}

\begin{abstract}
Abstrak
Peran dan tanggung jawab seorang guru sangat penting dalam mencapai tujuan pendidikan nasional. Guru adalah salah satu penentu tinggi rendahnya mutu pendidikan. Kinerja professional guru sangat berpengaruh terhadap kelangsungan seluruh proses pembelajaran di dalam kelas pada akhirnya akan mempengaruhi kualitas lulusan.Tujuan dari penelitian ini untuk mengetahui apakah terdapat pengaruh status sosial ekonomi terhadap kinerja guru ekonomi di SMA Kota Malang. Penelitian ini menggunakan metode penelitian deskriptif dengan pendekatan kuantitatif yang berfokus pada perbandingan antar variable yaitu variable $\mathrm{X}$ dan variable $\mathrm{Y}$. Penelitian ini merupakan penelitian eksplanatori. Subjek penelitian ini adalah guru Ekonomi di SMA Kota Malang yang berjumlah 82 guru di 10 SMA Negeri dan 34 SMA Swasta. Teknik pengumpulan data dengan angket. Teknik pengolahan data menggunakan spss Uji t yaitu untuk mencari korelasi antara variabel $\mathrm{X}$ dan $\mathrm{Y}$. Pada penghitungan hipotesis didapatkan nilai Sig 0,031. Hasil tersebut menunjukkan bahwa nilai Sig lebih kecil dari 0,05 (0,031 kurang dari 0,05$)$. Hal ini berarti hipotesis yang diajukan peneliti diterima yaitu terdapat pengaruh yang positif dan signifikan dalam penelitian yang berjudul "Pengaruh Status Sosial Ekonomi Terhadap Kinerja Guru Ekonomi di SMA Kota Malang" dapat teruji kebenarannya. Dengan demikian dapat disimpulkan bahwa status sosial ekonomi sangat berpengaruh dan signifikan terhadap kinerja guru. Dalam artian bahwa penelitian ini mampu menjawab kebenaran hipotesis yang diajukan.
\end{abstract}

Kata kunci : Status Sosial Ekonomi, Kinerja Guru

\begin{abstract}
The role and responsibility of a teacher is very important to achieve national education goal. Teacher is one of determinants of the high and low quality of education. The professional performance of teacher is very influential on the continuity of the entire learning process in the classroom to affect the quality of graduates. The purpose of this study is to determine whether there is an influence of socio-economic status on the performance of economics' teachers in Senior High Schools of Malang. This study used descriptive research method with a quantitative approach focusing on the comparison between variables, namely variables $\mathrm{X}$ and $\mathrm{Y}$. This research was an explanatory study. The subjects of this study were Economics' teachers in Senior High Schools of Malang, in which it were about 82 teachers of 10 Public High Schools and 34 Private High Schools. Data collection technique was using questionnaires. Moreover, data processing techniques was using spss t-test in order to find a correlation between variables $\mathrm{X}$ and $\mathrm{Y}$. In calculating the hypothesis, Sig 0.031 is obtained. These result indicates that the Sig value
\end{abstract}


is smaller than 0.05 (0.031 less than 0.05). It means that the hypothesis proposed by the researcher is accepted. Thus, there is a positive and significant influence in the research entitled "The Effect of Socio-Economic Status on the Performance of Economics' Teachers in Senior High Schools of Malang" can be verified. It can be concluded that socio-economic status influence so much, and it is significant towards teachers' performance. Therefore, this research is able to answer the truth of the hypothesis proposed.

Keywords: Socio-Economic Status, Teachers' Performance..

\section{PENDAHULUAN}

Kinerja guru yang profesional seharusnya dimiliki oleh setiap pendidik karena melalui kondisi tersebut dapat diperoleh pendidikan yang mampu membentuk manusia berkualitas. Peran dan tanggung jawab seorang guru sangat penting dalam mencapai tujuan pendidikan nasional. Guru adalah salah satu penentu tinggi rendahnya mutu pendidikan. Kinerja professional guru sangat berpengaruh terhadap kelangsungan seluruh proses pembelajaran di dalam kelas pada akhirnya akan mempengaruhi kualitas lulusan. Untuk mewujudkannya dapat dilakukan dengan ketersediaan pendidik yang berkualitas. Berbagai upaya sudah dilakukan untuk menghasilkan pendidik yang memiliki kinerja berkualitas. Kualitas kinerja guru akan sangat menentukan pada kualitas hasil pendidikan, karena guru merupakan pihak yang paling banyak bersentuhan langsung dengan siswa dalam proses pendidikan atau pembelajaran di lembaga pendidikan sekolah.

Meningkatnya kualitas pembelajaran yang dilaksanakan diberbagai jenjang pendidikan akan mampu meningkatkan kualitas pendidikan. Usaha peningkatan kualitas pendidikan akan berlangsung dengan baik manakala didukung kemauan para pengelola pendidikan untuk melakukan perbaikan secara terus-menerus menuju kearah yang lebih baik. Dengan demikian, inovasi pendidikan secara berkesinambungan dalam program pendidikan termasuk program pembelajaran merupakan tuntutan yang harus segera dilaksanakan.

Sekolah sebagai satu unit organisasi pendidikan formal merupakan wadah kerja sekelompok orang (kepala sekolah, guruguru, staf, dan siswa) untuk mencapai tujuan pendidikan. Pencapaian tujuan sekolah, baik dari kuantitas dan kualitasnya sangat tergantung pada orangorang yang tergabung di dalam lembaga sekolah itu, sebagaimana yang dikatakan oleh Griffihs (Gorton, 1991) bahwa secara aksioma suatu sekolah sama baiknya dengan orang-orang yang melaksanakannya. Secara khusus, keberhasilan sekolah banyak ditentukan oleh guru-guru dan kepala sekolah (Lave \& Conant seperti dikutip De Roche, 1985).Kinerja guru sangat dipengaruhi oleh berbagai faktor. Di satu pihak, ada kemungkinan kinerja guru-guru berhasil dalam pekerjaannya karena memiliki kemampuan dan keterampilan itu.

Guru sebagai tenaga pendidik merupakan pemimpin pendidikan, dia amat menentukan dalam proses pembelajaran di kelas, dan peran kepemimpinan tersebut akan tercermin dari bagaimana guru melaksanakan peran dan tugasnya, ini berarti bahwa kinerja guru merupakan faktor yang amat menentukan bagi mutu 
pembelajaran/pendidikan yang akan berimplikasi pada kualitas output pendidikan setelah menyelasaikan sekolah. Setiap guru bidang studi diharapkan memiliki kinerja yang profesional, termasuk juga guru mata pelajaran ekonomi.

Salah satu faktor yang meramaikan pembincangan tentang carut-marutnya mutu pendidikan di Indonesia adalah status sosial ekonomi guru. Eggen \& Kauchak (2004) dalam penelitiannya menemukan bahwa status sosial ekonomi merupakan salah satu dari sekian banyak faktor yang paling berpengaruh terhadap kinerja sekolah. Pengembangan sumberdaya manusia (SDM) guru hanya mempunyai arti apabila diarahkan juga kepada upaya untuk mewujudkan pembangunan ekonomi guru. Apabila keuangan rumah tangga guru tidak tercukupi, guru tidak akan bisa bekerja dengan tenang. Pikirannya sangat kacau karena banyak urusan ekonomi rumah tangga yang belum terselesaikan. Akibatnya, kinerja guru di sekolah dan terutama di kelas menjadi sangat terganggu. Ada banyak peristiwa yang menimbulkan masalah bisa saja terjadi karena kondisi kejiwaan guru yang tidak tenang (Sahertian, 2000)

Sejauh penelusuran peneliti, penelitipeneliti sebelumnya lebih banyak menyoroti dan/atau membahas status sosial ekonomi orang tua pada umunya dan dampaknya terhadap pendidikan dan/atau prestasi belajar siswa di sekolah dan kinerja peserta pelatihan, namun jarang menyentuh secara khusus status sosial ekonomi guru dan dampaknya terhadap kinerjanya di sekolah dan/atau di dalam kelas. Padahal sebagian besar guru-guru adalah juga orang tua yang memiliki beban hidup dan tanggung jawab terhadap jutaan anak-anaknya yang menjadi siswa dari sekolah-sekolah yang ada.

Jika di dalam komunitas masyarakat paguyuban profesi guru masih memiliki daya tawar yang tinggi, tidak demikian di dalam komunitas masyarakat patembayan, status guru dipandang secara 'terhormat' bukan dari aspek moral dan spiritualnya, tetapi terlebih dari aspek pendidikan, pekerjaan, penghasilan dan kualitas rumah tempat hunian. Dengan kata lain, guru dipandang 'terhormat' lebih karena faktor financial dari materi (harta kekayaan) yang dimilikinya.

Perkembangan pandangan berarti seperti yang dipaparkan di atas 'telah mendorong' para ahli sosial ekonomi dan, tidak ketinggalan para ahli pendidikan untuk mengukur status sosial ekonomi seseorang di dalam masyarakat berdasarkan pendapatan keluarga, pekerjaan dan tingkatan pendidikannya. Stratifikasi masyarakat Indonesia, menurut Sukamto (1982), pada umunya di dasarkan pada latar belakang keluarga, suku bangsa, pendidikan, pekerjaan dan kekayaan material yang dimiliki seseorang. Senada dengan itu Waltler (1992:626) mengatakan sebagai berikut:"Sosioeconomic status refers to some combination of familial income, education and employment" (Status sosial ekonomi merujuk kepada kombinasi antara penghasilan keluarga, pendidikan dan pekerjaan).

Hasil penelitian Dewi Retno Mustika (2012) telah menunjukkan terdapat pengaruh yang positif variabel status sosial ekonomi terhadap kinerja professional guru, sedangkan Sri Handayani (2012) menunjukkan status sosial ekonomi tidak berpengaruh terhadap kinerja guru. 
Perbedaan hasil penelitian di atas membuat peneliti tertarik untuk melakukan penelitian karena status sosial ekonomi guru di setiap sekolah berbeda-beda, selain itu masih banyak guru yang mencari keuangan tambahan dengan kerja lain selain profesi guru.

Banyak hal yang menjadi pertimbangan untuk melihat bagaimana kinerja guru ekonomi akan berdampak positif pada dunia pendidikan. Usaha meningkatkan kualitas pendidikan ekonomi tanpa prioritas perbaikan kualitas guru merupakan hal yang tidak mungkin. Hal ini disebabkan karena ekonomi merupakan hal yang dominan ingin dicapai oleh pemerintah dengan segala indikatornya. Ilmu ekonomi pun terus mengalami perkembangan pemikiran yang besar.

Guru mata pelajaran ekonomi SMA merupakan seseorang yang memiliki kompetensi sebagai pengajar ekonomi di tingkat satuan pendidikan menengah. Guru mata pelajaran ekonomi SMA mempunyai tugas dan fungsi yang cukup berat dan strategis pada era globalisasi yang dituntut untuk mampu menghadapi persaingan yang semakin ketat di segala bidang ekonomi.

\section{KAJIAN LITERATUR \\ Tinjauan tentang Guru}

Definisi guru diatur dalam Undangundang Nomor 14 Tahun 2005 (Pasal 1 ayat 1) tentang Guru dan Dosen (dalam Martines, 2009). Guru adalah pendidik profesional dengan tugas utama mendidik, mengajar, membimbing, mengarahkan, melatih, menilai, dan mengevaluasi peserta didik pada jenjang pendidikan anak usia dini, pendidikan dasar, dan pendidikan menengah pada jalur pendidikan formal.

Guru memiliki tugas utama untuk mendidik, mengajar, membimbing, mengarahkan, melatih, menilai, dan mengevaluasi peserta didik, maka akan dijelaskan tentang rincian dari tugas utama guru tersebut.

\section{Tinjauan tentang Kinerja Guru}

Lowler (1984) menyatakan bahwa "kinerja guru berhubungan dengan kemampuan dan kecakapan melakukan sesuatu". Selanjutnya, Kast dan Rosenzweig (1979) yang didukung oleh Hoy dan Miskel (1978) menyatakan bahwa "kinerja guru merupakan suatu kemampuan dalam melaksanakan tugas atau pekerjaan yang sesuai dengan sikap, pengetahuan, dan keterampilan serta motivasi". Pendapat ini senada dengan yang dikemukakan Vroom dan Deci (1970) bahwa Kinerja seseorang dalam mengerjakan sesuatu pekerjaan, berkaitan dengan kemampuan atau keterampilan orang tersebut dalam menggunakan kemampuan dan keterampilannya ketika melaksanakan pekerjaan yang dibebankan kepadanya.

Kinerja juga bisa didefinisikan sebagai kesediaan seseorang atau kelompok orang untuk melakukan suatu kegiatan sesuai dengan tanggung jawabnya agar memperoleh hasil yang diharapkan. Kinerja dalam menjalankan fungsinya tidak berdiri sendiri, akan tetapi berhubungan dengan kepuasan kerja dan tingkat imbalan, dan dipengaruhi oleh keterampilan, kemampuan, dan sifat-sifat individu. Oleh karena itu, menurut model partner-lawyer (Donnelly, Gibson, and Invancevich: 1994), kinerja individu pada dasarnya dipengaruhi oleh faktor-faktor; a) 
harapan mengenai imbalan; b) dorongan; c) kemampuan, kebutuhan dan sifat; d) persepsi terhadap tugas; e) imbalan internal dan eksternal; f) persepsi terhadap tingkat imbalan dan kepuasan kerja. Dengan demikian, kinerja pada dasarnya ditentukan oleh tiga hal, yaitu: 1) kemampuan, 2) keinginan dan 3) lingkungan.

Oleh karena itu, untuk memperoleh kinerja yang baik, seseorang harus mempunyai keinginan yang tinggi untuk mengerjakan serta mengetahui pekerjaannya. Tanpa mengetahui ketiga faktor ini kinerja yang baik tidak akan tercapai. Dengan kata lain, kinerja individu dapat ditingkatkan apabila ada kesesuaian antara pekerjaan dan kemampuan. Kinerja individu dipengaruhi oleh kepuasan kerja. Perasaan ini berupa suatu hasil penilaian mengenai seberapa jauh pekerjaannya secara keseluruhan mampu memuaskan kebutuhannya.

Menurut Robert L. Mathis dan John H. Jackson (2001) faktor-faktor yang mempengaruhi kinerja individu tenaga kerja, yaitu: 1) kemampuan mereka; 2) motivasi; 3) dukungan yang diterima; 4) keberadaan pekerjaan yang mereka lakukan; dan 5) hubungan mereka dengan organisasi. Dari penjabaran tersebut disimpulkan bahwa kinerja merupakan kaulitas dan kuantitas dari suatu hasil kerja (output) individu maupun kelompok dalam suatu aktivitas tertentu yang diakibatkan oleh kemampuan alami atau kemampuan yang diperoleh dari proses belajar serta keinginan untuk berprestasi.

Gary dan Margaret (dalam Mulyasa, 2007) mengemukakan guru yang efektif dan kompeten secara profesional memiliki karakter (a) memiliki kemampuan menciptakan pembelajaran yang kondusif, (b) memiliki kemampuan mengembangkan strategi dan manajemen pengajaran, dan (c) memiliki kemampuan memberikan umpan balik (feedback) dan penguatan (reinforcement), (d) memiliki kemampuan untuk meningkatkan diri. Pemahaman bahwa kinerja guru tidak dapat dipisahkan dari kompetensi profesionalnya, juga dapat dirunut dari pendapat Mulyasa (2007) yang menyatakan bahwa salah satu upaya yang dilakukan oleh pemerintah untuk meningkatkan kinerja guru adalah melalui standar kompetensi dan sertifikasi guru.

Direktorat Jenderal Peningkatan Mutu Tenaga Kependidikan (Ditjen PMPTK) menyebutkan bahwa tugas guru mencakup lima hal yaitu: (a) merencanakan pengajaran, (b) melaksanakan pengajaran, (c) menilai hasil pengajaran, (d) membimbing dan melatih peserta didik, dan (e) melaksanakan tugas tambahan (Depdiknas, 2008). Hal ini sejalan dengan Mulyasa (2007) yang menyebutkan bahwa tugas guru mencakup tiga bidang yaitu: (a) mendidik, mengajar, membimbing, da melatih, (b) membantu pengelolaan dan pengembangan sekolah, dan (c) mengembangkan profesionalisme. Sedangkan fungsi guru terkait dengan tugas pertama adalah sebagai pendidik, pengajar, pembimbing, dan pelatih. Fungsi guru sesuai dengan tugas kedua adalah sebagai pengembang program dan pengelolaan program, dan terakhir fungsi untuk mengembangkan keprofesionalisme adalah sebagai tenaga profesionalisme.

Berdasarkan dari pemahaman tentang kinerja dan tugas guru yang diemban guru dapat menarik pemahaman bahwa kinerja guru adalah pencapaian kerja guru dalam menyelesaikan tugas-tugas yang 
dibebankan kepadanya sesuai dengan undang-undang atau peraturan yang berlaku dengan bekal pengetahuan, sikap, dan keterampilan yang didukung oleh berbagai faktor eksternal.

\section{Aspek-aspek Kinerja Guru}

Menurut Salladien (2002) menyatakan bahwa faktor yang paling menentukan tinggi rendahnya kinerja seorang guru adalah kualifikasi guru. Salladien (2002) mendefinisikan kualifikasi guru sebagai tingkat kesesuaian antara pendidikan guru dengan mata pelajaran yang diajarkan. Penegasan ini mempersyaratkan bahwa upaya peningkatan kinerja guru harus ditunjang oleh peningkatan kualifikasi guru.

Sementara itu, Mitchel (1978) mengemukakan 5 (lima) aspek kinerja sebagai berikut:

1) Kualitas kerja: tinggi-rendahnya sskinerja seseorang dapat diukur melalui kualitas kerja yang dihasilkan oleh orang tersebut

2) Ketepatan: kinerja seseorang dapat juga dilihat dari tepat-tidaknya orang melaksanakan pekerjaannya sesuai dengan petunjuk dan garis kebijakan yang sudah ditetapkan.

3) Inisiatif: seseorang yang memiliki tingkat inisiatif yang tinggi biasanya memiliki kinerja yang baik. Semua potensi diri dikerahkan untuk meningkatkan hasil kerjanya.

4) Kapabilitas: kinerja seseorang dapat juga diamati melalui kapabilitas seseorang dalam melaksanakan dan menyelesaikan pekerjaan yang dipercayakan kepadanya.

5) Komunikasi: orang yang memiliki tingkat komunikasi yang baik dengan atasan, bawahan dan rekan-rekan sejawat biasanya mampu mengimprovisasi segenap potensi dirinya untuk mencapai tujuan organisasi.

\section{Status Sosial Ekonomi}

\section{Tinjauan tentang Status Sosial Ekonomi}

Starifikasi sosial berhubungan dengan adanya dua atau lebih kelompokkelompok bertingkat yang para anggotanya memiliki kekuasaan dan prestise yang berbeda dari kelompok lainnya dalam suatu masyarakat. Sedangkan ketidaksamaan sosial lebih merujuk kepada perbedaan derajat dalam pengaruh dan prestise sosial antar individu dalam suatu masyarakat.

Kata guru berasal dari bahasa Sansekerta yang berarti "yang dihormati'. Guru sebenarnya adalah seorang pembimbing spiritual bagi seseorang atau kelompok. Guru sebenarnya adalah seorang dari Kasta Brahmin. Para Brahmin memiliki hakhak khusus di dalam masyarakat dan mereka di beri gelar kaum Mahardika atau Begawan. Para Begawan memiliki kedudukan yang tinggi sehingga mendapat hak- hak istimewa, seperti tidak membayar pajak. Selanjutnya, guru dipandang sebagai penjelmaan hidup spiritual kebenaran. Dalam kerangka pemikiran inilah, para siswa menyerahkan sepenuh dan sebulatbulatnya akal budi, tubuh dan hak milik kepada guru.

Di negara kita, khususnya di daerah pedesaan, masyarakat masih tetap memberikan penghargaan dan status sosial ekonomi yang tinggi kepada profesi guru. Guru ditempatkan pada status sebagai sumber ilmu dan pengetahuan ketika media informasi 
masih amat terbatas dan karena itu dipandang sebagai sosok yang harus 'digugu dan ditiru'. Citra guru yang sedemikian tinggi dan luhur tersebut lambat laun memudar seiring dengan adanya perubahan dan perkembangan masyarakat dari sebuah komunitas paguyuban menjadi sebuh komunitas patembayan. Jika di dalam komunitas masyarakat paguyuban profesi guru masih memiliki daya tawar tinggi, tidak demikian di dalam komunitas masyarakat patembayan yang serba individualistis dan materialistis.

Dalam komunitas masyarakat patembayan, status guru dipandang secara terhormat bukan dari aspek moral dan spiritualnya, tetapi lebih ditekankan pada dari aspek pendidikan, pekerjaan, dan penghasilan dan kualitas rumah tempat hunian. Dengan kata lain, guru dipandang terhormat lebih karena faktor finansial dan materi (harta kekayaan) yang dimilikinya.

Status sosial ekonomi pada saat ini sering diukur dari segi uang dan harta. Seseorang mempunyai status sosial ekonomi tinggi kalau dia orang kaya atau memiliki kedudukan. Guru termasuk kelompok yang gajinya kecil. Dari fenomena tersebut status guru dipandang rendah oleh masyarakat. Hal ini karena (1) kurang pentingnya peranan guru karena kurang dihargai oleh masyarakat karena gaji guru kecil; (b) mengajar adalah pekerjaan tetap dan rutin dan dipandang sebagai suatu kebutuhan yang biasa saja, sementara dokter atau pengacara pada saat tertentu dapat diperlukan secara cepat dan tiba- tiba. Keperluan yang tiba-tiba ini memberikan kepada dokter atau pengacara prestasi sosial dan penghargaan khusus yang secara khusus dibutuhkan oleh masyarakat; (c) guru berhubungan dengan anak didik untuk waktu yang lama, sementara dokter atau pengacara berhubungan dengan orang tertentu karena adanya kebutuhan yang harus diselesaikan; (d) masyarakat cenderung lebih menghargai keahlian khusus, sehingga orang lebih banyak menaruh penghargaan kepada orang yang memiliki keahlian khusus.

Pandangan yang berkembang tersebut telah mendorong para ahli sosial-ekonomi dan para ahli pendidikan untuk mengukur status sosial ekonomiekonomi seseorang di dalam masyarakat berdasarkan pendapatan keluarga, pekerjaan dan tingkat pendidikannya.

Berdasarkan definisi di atas, dapat dinyatakan bahwa status sosial ekonomi guru merupakan kedudukan seorang guru dalam hubungannya dengan orang lain di dalam suatu masyarakat berdasarkan pendidikan, pekerjaan, pendapatan dan rumah yang dihuni. Status sosial ekonomi mempengaruhi kemampuan suatu keluarga untuk memenuhi kebutuhan dasar anggota keluarga seperti perumahan yang layak huni, makanan bergizi, kesehatan, pakaian, kebutuhan rumah tangga dan perasaan aman di dalam diri anak- anak.

Guru yang terpenuhi kebutuhan keuangan, rumah tangganya akan lebih merasa aman, tenang dan memiliki hubungan sosial yang baik dengan orang lain (Albatch,1982). Guru yang memiliki penghasilan tinggi tidak hanya memungkinkan tercukupinya pemenuhan kebutuhan dasar keluarga, tetapi juga dapat memungkinkan tersedianya 
fasilitas belajar yang memadai di rumah untuk pengembangan kemampuan diri dan anak- anaknya (Albatch, 1982). Sebaliknya, apabila kebutuhan keuangan rumah tangga tidak terpenuhi, guru tidak akan bisa bekerja dengan tenang.

Status sosial ekonomi berarti keadaan yang berkenaan dengan kemasyarakatan yang selalu mengalami perubahan- perubahan melalui proses sosial yang terjadi melalui proses interaksi sosial. Menurut Abdulsyani (2002) interaksi sosial diartikan sebagai hubungan- hubungan timbal balik yang dinamis yang menyangkut hubungan antara orang- orang secara perseorangan, antara kelompok manusia maupun antara orang dengan kelompok- kelompok manusia. Status ekonomi adalah kenyataan yang terlihat atau terasakan oleh indra manusia tentang keadaan seseorang dalam memenuhi kebutuhannya (Heini, 1999). Salah satu hal yang berkaitan dengan kondisi ekonomi adalah pendapatan. Pendapatan adalah semua penghasilan yang diperoleh dari phak lain sebagai balas jasa yang diberikannya dimana penghasilannya tersebut digunakan untuk memenuhi kebutuhan keluarga atau perseorangan. Disini, pendapatan adalah dasar dalam penghidupan, dimana besarnya pendapatan akan memenuhi jumlah kebutuhan yang hendak dipuaskan.

Status sosial ekonomi (socioeconomic status) jika dikaji dari sudut pandang sosiologi adalah perangkat atau stratifikasi masyarakat secara sosialekonomi. Terjadinya status sosial ekonomi salah satunya disebabkan oleh adanya perubahan masyarakat dari tradisional menuju ke arah modern yang menimbulkan pergeseran peran serta fungsi dari lembaga lama menjadi ke yang baru. Pergeseran-pergeseran tersebut melahirkan sejumlah teori pelapisan sosial. Penyebab dari adanya pelapisan sosial dalam masyarakat bukan saja karena ada perbedaan, tetapi karena kemampuan manusia di dalam menilai perbedaan itu dengan menerapkan berbagai kriteria. Perbedaan tersebut menggambarkan bahwa ada sesuatu yang dihargai berupa uang ataupun benda yang bernilai ekonomis, kekuasaan, ilmu pengetahuan, atau keturunan keluarga yang terhormat.

\section{METODE PENELITIAN}

Penelitian ini menggunakan metode penelitian deskriptif dengan pendekatan kuantitatif yang berfukus pada perbandingan antar variable yaitu variable $X$ dan variable $Y$. Subjek penelitian ini adalah guru ekonomi di SMA Kota Malang. Teknik pengumpulan data dengan angket. Teknik pengolahan data yaitu menggunakan spss.

\section{HASIL PENELITIAN DAN PEMBAHASAN}

Berdasarkan hasil perhitungan bahwa sebesar $71,62 \%$ responden (53 guru) memiliki status sosial ekonomi yang rendah, 20,27\% (15 guru) memiliki status sosial ekonomi yang tinggi, sekitar 1,35\% (1 guru) memiliki status sosial ekonomi yang sangat tinggi dan $6,76 \%$ (5 guru) memiliki status sosial ekonomi yang sangat rendah.

Berdasarkan hasil perhitungan bahwa sebagian besar responden yakni 75,68\% (56 guru) menyatakan tingkat kinerja guru sangat baik, sekitar 22,97 (17 guru) 
menyatakan kinerja guru baik, sedangkan 1,35 (1 guru) menyatakan kinerja guru tidak baik.

Dari hasil perhitungan bahwa nilai constant (a) untuk variable $\mathrm{X}$ adalah 91.325, sedangkan hasil nilai koefisien untuk variable $\mathrm{X}$ adalah 0.782 .

Persamaan regresi $Y^{\prime}=91.325+$ 0.782 , kemudian diuji apakah memang valid untuk memprediksi variabel terikatnya. Artinya apakah variable $\mathrm{X}$ benar-benar dapat memprediksi variable Y. Hasil dari analisis di atas terbukti bahwa koefisien konstanta pada model linier $(\alpha)$ signifikan karena nilai signifikan dari adalah 0,000, jauh lebih besar dari 0,05 . Kemudian hasil dari uji signifikansi koefisien regresi variabel $\mathrm{X} \quad(b)$ menunjukkan signifikan karena nilai signifikan dari adalah 0,000, jauh lebih besar dari taraf signifikan 5\% atau 0,05. Koefisien konstanta pada model linier $(b)$ dan koefisien regresi variabel X $(\alpha)$ signifikan. jadi variable $\mathrm{X}$ berpengaruh terhadap variable $Y$.

Sehingga persamaan regresi dapat dijelaskan sebagai berikut:

1. Nilai konstanta memiliki nilai 91.325, artinya jika variable $X$ nilainya 0 , maka variable $\mathrm{Y}$ nilainya 91.325 .

2. Koefisien regresi $X$ sebesar 0.782, artinya setiap penambahan nilai 1 satuan, maka nilai variable $\mathrm{Y}$ sebesar 0.782. Dan sebaliknya jika nilai variable $\mathrm{X}$ turun 1 poin maka nilai dari variable $\mathrm{Y}$ juga mengalami penurunan sebesar 0,782 poin.

Interpretesi dari persamaan di atas adalah bahwa koefisien regresi variable $\mathrm{X}$ memiliki tanda positif (0.782), yaitu mengandung implikasi bahwa variable $\mathrm{X}$ searah dengan variable $\mathrm{Y}$. dengan kata lain bahwa variable $\mathrm{X}$ mempunyai pengaruh yang positif terhadap variable $Y$.

Dapat juga disimpulkan dengan uji $\mathrm{t}$ yaitu untuk mengetahui apakah diterima atau tidaknya hipotesis variable $X$ terhadap variable Y. Tabel 3.didapatkan nilai Sig 0,031. Hasil tersebut menunjukkan bahwa nilai Sig lebih kecil dari 0,05 (0,031 kurang dari 0,05). Sehingga dapat disimpulkan bahwa $\mathrm{H}_{0}$ yang berbunyi “ Tidak ada pengaruh yang signifikan antara status sosial ekonomi terhadap kinerja guru ekonomi di SMA Kota Malang" di tolak. $\mathrm{H}_{1}$ yang berbunyi "Ada pengaruh yang signifikan antara status sosial ekonomi terhadap kinerja guru ekonomi di SMA Kota Malang" di terima.

Nilai koefisien regresi parsial (B) variabel status sosial ekonomi bernilai 0,782, berarti jika status sosial ekonomi dinaikkan satu satuan, maka status sosial ekonomi akan naik sebesar 0,782. Seseorang yang memiliki status sosial ekonomi yang tinggi mampu memenuhi kebutuhan maupun keinginannya sehingga dengan demikian dapat fokus pada satu pekerjaan dibandingkan dengan seseorang yang mempunyai status sosial ekonomi yang rendah.

Dengan demikian dapat disimpulkan bahwa ada pengaruh yang signifikan status sosial ekonomi terharap kinerja guru ekonomi di SMA Kota Malang.

\section{KESIMPULAN DAN SARAN}

Dari hasil penelitian bahwa status sosial ekonomi berpengaruh secara langsung terhadap kinerja guru ekonomi di SMA Kota Malang. Hal ini dikarenakan seorang guru dengan status sosial yang tinggi akan mampu fokus pada 
pekerjaannya yaitu sebagai tenaga pendidik tanpa harus memikirkan pekerjaan sampingan untuk mendapatkan tambahan pemasukan agar tercukupi kebutuhan sehari-hari. Sehingga kinerja guru di sekolah sebagai tenaga pendidik berjalan dengan lancar.

\section{DAFTAR RUJUKAN}

Depdiknas, 2004. Panduan Broad Based Education, Jakarta: Depdiknas.

Dewi, Retno Mustika. 2010. Pengaruh Budaya Akademik dan Status Sosial Ekonomi terhadap Kinerja Profesional Guru Ekonomi SMA SeKota Malang. Tesis tidak diterbitkan. Program Pascasarjana. Universitas Negeri Malang.

Fried, Morton. 1976. The Evolution of Political Society. New York: Randon House

Handayani, Sri. 2012. Faktor-faktor Internal yang Mempengaruhi Kinerja Guru Ekonomi SMA Se-Malang Raya. Tesis tidak diterbitkan. Program Pascasarjana. Universitas Negeri Malang.

Harris, B.M.,et. Al.,1979. Personnel Administration in Educational. Boston: Allyn and Bacon, Inc.

Hoy. W.K dan Miskel, C.G., 1987. Educational Administration: Theory, Reseach, and Practice. New York: Random House.

Ivancevich, J. M. 2006. Perilaku dan Manajemen Organisasi. Alih Bahasa oleh Gina Gania. Jakarta: Erlangga.

Kast, F. E., \& Rosenzweig. 1979.

Organizational and Management Perilaku Organisasi, A System and
Contingency Approach. Tokyo:

McGraw-Hill

Mathis, L.R \& Jackson, J.H. 2000. Human Resource Management. $9^{\text {th }}$ Edition. Ohio, Cincinati: South Western College Publising

Mulyasa, E. 2003.Kurikulum Berbasis Kompetensi: Konsep, Karakteristik, dan Implementasi. Bandung: Remaja Rosdakarya.

Musfah, J. 2011. Peningkatan Kompetensi Guru Melalui Pelatihan dan

Sumber Belajar Teori dan Praktik. Jakarta: Kencana

Nadler, L. 1987. Designing Training Programs The Critical Events Model. Massachusetts: Addison-Wesley Publising Company.

Peraturan Pemerintah Nomor 19 Tahun 2005 tentang Standar Nasional Pendidikan, Jakarta: Departemen Pendidikan Nasional

Salladien, 2002. Metode Penelitian Pendidikan. Malang. Percetakan IKIP Malang

Sanderson, Stephen, K. 1993. Sosiologi Makro Sebuah Pendekatan Terhadap Realitas Sosial (terj. Farid Fajidi \& S Menno). Jakarta: PT. Rajawali Pers Steers, RM., \& Porter, L. W., 1983. Motivation and Work Behavior. New York : McGraw-Hill Book Company Undang-Undang Republik Indonesia Nomor 14 Tahun 2005 tentang Guru dan Dosen. 2008. Jakarta: Sinar Grafika. 


\section{Lampiran}

Table 1. : Distribusi Frekuensi Variabel Status Sosial Ekonomi

\begin{tabular}{|l|l|l|l|}
\hline Klasifikasi & Interval & Frekuensi & Persentasi \\
\hline Sangat tinggi & $30-36$ & 1 & $1,35 \%$ \\
\hline Tinggi & $23-29$ & 15 & $20,27 \%$ \\
\hline Rendah & $16-22$ & 53 & $71,62 \%$ \\
\hline Sangat rendah & $9-15$ & 5 & $6,67 \%$ \\
\hline Jumlah & & 74 & 100 \\
\hline
\end{tabular}

Table 2. : Distribusi Frekuensi Variabel Kinerja Guru

\begin{tabular}{|l|l|l|l|}
\hline Klasifikasi & Interval & Frekuensi & Persentasi \\
\hline Sangat tinggi & $100-122$ & 56 & $75,68 \%$ \\
\hline Tinggi & $77-99$ & 17 & $22,97 \%$ \\
\hline Rendah & $54-76$ & 1 & $1,35 \%$ \\
\hline Sangat rendah & $31-53$ & - & - \\
\hline Jumlah & & 74 & 100 \\
\hline
\end{tabular}

Tabel 3 : Coefficients ${ }^{\mathrm{a}}$

\begin{tabular}{|c|r|r|r|r|r|}
\hline \multicolumn{1}{|c|}{ Model } & \multicolumn{2}{|c|}{ Unstandardized coefficients } & $\begin{array}{r}\text { Standardized } \\
\text { Coefficients }\end{array}$ & \multirow{2}{*}{$\mathrm{T}$} & Sig \\
\hline & B & Std. error & Beta & & \\
\hline 1 (Constant) & 91.325 & 7.400 & & 12.341 & .000 \\
Status sosial ekonomi & .782 & .356 & .251 & 2.196 & .031 \\
\hline $\begin{array}{l}\text { a. Dependent } \\
\text { Variable: } \\
\text { Kinerja Guru }\end{array}$ & & & & & \\
\hline
\end{tabular}

